\title{
Atlas of marine bony fish otoliths (sagittae) of Southeastern-Southern Brazil Part III: Clupeiformes (Clupeidae, Engraulidae, Pristigasteridae)
}

\author{
Carolina Correia Siliprandi, Marina Rito Brenha-Nunes, \\ Carmen Lucia Del Bianco Rossi-Wongtschowski*, Cesar Santificetur, \\ Valéria Regina Martins Conversani
}

Instituto Oceanográfico da Universidade de São Paulo

(Praça do Oceanográfico, 191, 05508-120 São Paulo, SP, Brazil)

*Corresponding author: cwongski@usp.br

\section{Abstract}

This publication is the second in a series that will together constitute an Atlas of Teleostei Otoliths for the Southeastern-Southern Brazilian area. Here we present results of morphologic and morphometric analyses of 12 Clupeiform species (3 Clupeidae, 7 Engraulidae and 2 Pristigasteridae) by means of the most commonly used features, measurements and indices. Three otoliths of each species have been illustrated and photographed whenever possible. The frequency of occurrence has been calculated for each characteristic by total length class (TL), and the ontogenetic differences have been analyzed (multiple $\chi^{2}$ test; significance 0.05 ).

Descriptors: Otoliths, Morphology, Morphometry, Southwestern Atlantic, Brazil, Clupeiformes.

\section{Resumo}

Esta publicação é a segunda de uma série que constituirá um Atlas de Otólitos para os Teleostei da região Sudeste-Sul brasileira. Nela são apresentados os resultados de análises morfológicas e morfométricas de 12 espécies de Clupeiformes (3 Clupeidae, 7 Engraulidae e 2 Pristigasteridae) através de feições, medidas e índices usualmente utilizados. Três otólitos de cada espécie foram desenhados e fotografados, sempre que possível. A frequência de ocorrência foi calculada para cada característica por classes de comprimento total dos peixes (CT) e as diferenças ontogenéticas foram analisadas (Teste $\chi^{2}$ múltiplo; significância 0,05 ).

Descritores: Otólitos, Morfologia, Morfometria, Atlântico Sudoeste, Brasil, Clupeiformes.

\section{INTRODUCTION}

Otolith size and shape differ among species, among populations and within each species. These variations are influenced during development by both genetic and environmental factors. Due to their intra and interspecific variation in shape, otoliths are useful in many studies: taxonomy, phylogeny, archeology, paleontology, species' geographical variation, stock identification, food webs and others.

Many papers have been published since the 1980s showing the value of photographs and drawings in the analysis of otolith features. Parallel to this development, otolith collections have proved to be useful in the analysis of past populations' genetics and populations' structure, growth dynamics and environmental conditions.

Recently, during the $5^{\text {th }}$ International Otolith Symposium, held in Palma de Mallorca, between 20 and 24 October 2014, the latest developments in otolith analytical techniques and novel applications were presented. A special workshop on otolith shape analysis was held focusing on these structures as indicators for community, population and individual analysis, and environmental events.

The Collection of Teleostei Fish Otoliths of the Southeastern-Southern Brazilian region (COSS-Brasil) held at the Instituto Oceanográfico - USP, (IOUSP) contains around 45,000 pairs of otoliths from 210 species.

Following ROSSI-WONGTSCHOWSKI et al. (2014), in this second publication (PART III) of a series that will together constitute an Atlas of Otoliths of the Southeastern-southern Brazilian region we present the results of the morphologic and morphometric analyses of Clupeiformes species (3 Clupeidae, 7 Engraulidae and 2 Pristigasteridae), by means of the most commonly used features, measurements and indices. 


\section{MATERIAL AND METHODS}

The sampling area and the methodology followed those presented in ROSSI-WONGTSCHOWSKI et al. (2014).

The acronyms in the shape indices tables represent: $\mathrm{TL}=$ total fish length, $\mathrm{OL}=$ otolith length, $\mathrm{OH}=$ otolith height and $\mathrm{OT}=$ otolith thickness.

\section{RESULTS}

\section{FAMILY CLUPEIDAE}

Otolith shape tends to be rectangular, the anterior region is clearly peaked to lanceolated, the rostrum and antirostrum being well developed and the pseudorostrum and pseudoantirostrum always absent.

\section{Harengula clupeola (Cuvier 1829) - Plate 1}

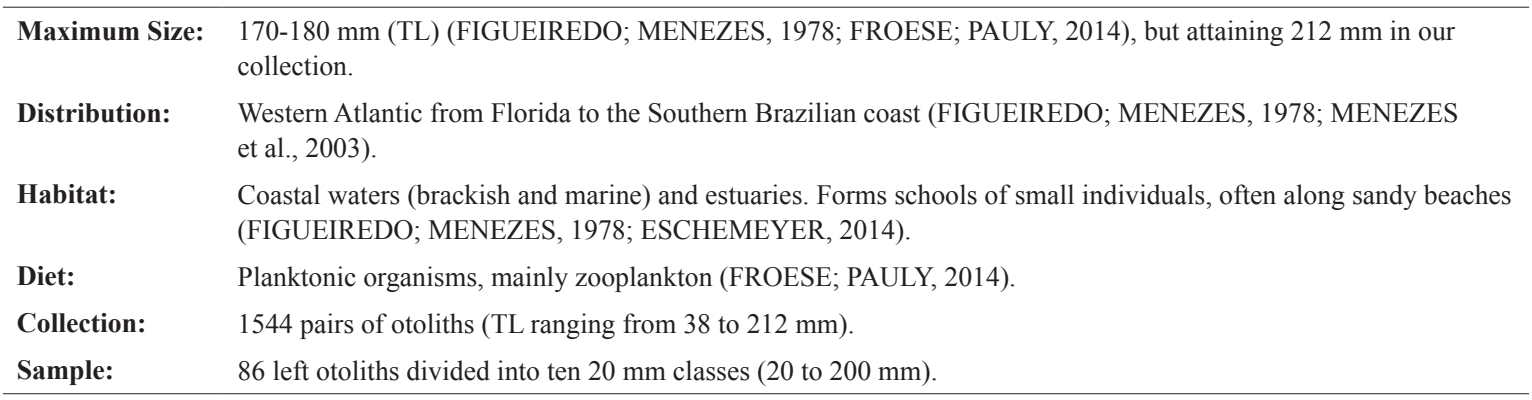

Shape: elliptic to rectangular (52.33\%), rectangular, elliptic. Anterior region: peaked (97.67\%), peaked-round. Posterior region: round (86.05\%), angled-round. Dorsal edge: sinuate to entire (75.58\%), entire, lobed to sinuate. Ventral edge: lobed to sinuate (44.19\%), dentate to sinuate, sinuate to entire. Profile: concave-convex (88.37\%), plane. Rostrum and antirostrum orientation: in agreement (88.37\%), in disagreement. Rostrum: developed. Antirostrum: developed. Sulcus acusticus: position: median; orientation: slightly ascending (52.33\%), horizontal (47.67\%); opening: ostial; morphology: heterosulcoid (88.37\%), pseudo-archaesulcoid; colliculum: heteromorphic; ostium: funnel-like; cauda: elliptic (50\%), oval, tubular slightly curved.

Significant differences $(p<0.05)$ were found within some length classes for otolith shape, anterior and posterior regions, dorsal and ventral edges, sulcus acusticus and cauda morphology, otolith profile, rostrum and antirostrum orientation. Over the period of the fishes' development differences were found in otolith shape, anterior and posterior regions, dorsal edge, sulcus acusticus orientation and morphology, cauda morphology, profile and rostrum and antirostrum orientation.

\begin{tabular}{lccc}
\hline Shape indices & Mean \pm SD & Minimum & Maximum \\
\hline OL/TL (\%) & $2.30 \pm 0.33$ & 1.66 & 3.11 \\
OH/OL (\%) & $57.15 \pm 3.06$ & 51.41 & 66.67 \\
OT/OL (\%) & $21.03 \pm 2.38$ & 15.53 & 30.11 \\
OT/OH (\%) & $36.77 \pm 3.34$ & 29.60 & 46.55 \\
Circularity & $21.85 \pm 2.36$ & 16.36 & 27.38 \\
Rectangularity & $0.71 \pm 0.02$ & 0.67 & 0.75 \\
\hline
\end{tabular}


Opisthonema oglinum (Lesueur 1818) - Plate 2

\begin{tabular}{|c|c|}
\hline Maximum Size: & 300 mm (TL) (FIGUEIREDO; MENEZES, 1978). \\
\hline Distribution: & Gulf of Maine to Argentina (FIGUEIREDO; MENEZES, 1978; MENEZES et al., 2003; ESCHEMEYER, 2014). \\
\hline Habitat: & $\begin{array}{l}\text { Shallow and coastal waters (brackish and marine). Forms shoals (FIGUEIREDO; MENEZES, 1978; } \\
\text { ESCHEMEYER, 2014). }\end{array}$ \\
\hline Diet: & $\begin{array}{l}\text { Filtering plankton (copepods) and also small fishes, crabs and shrimps (FURTADO-OGAWA, 1970; FROESE; } \\
\text { PAULY, 2014). }\end{array}$ \\
\hline Collection: & 439 pairs of otoliths (TL ranging from 85 to $312 \mathrm{~mm}$ ). \\
\hline Sample: & 88 left otoliths divided into eleven $20 \mathrm{~mm}$ classes (100 to $300 \mathrm{~mm}$ ). \\
\hline
\end{tabular}

Shape: rectangular to lanceolated (97.73\%), rectangular. Anterior region: lanceolated (97.73\%), peaked. Posterior region: round. Dorsal edge: sinuate to entire (55.68\%), sinuate, entire, lobed to entire. Ventral edge: dentate to entire (46.59\%), dentate to sinuate, lobed to sinuate, sinuate to entire. Profile: concave-convex (94.32\%), flattened. Rostrum and antirostrum orientation: in agreement (68.18\%), in disagreement. Rostrum: developed. Antirostrum: developed. Sulcus acusticus: position: median; orientation: horizontal (92.05\%), slightly ascending; opening: ostial; morphology: pseudo-archaesulcoid (65.91\%), heterosulcoid; colliculum: heteromorphic; ostium: funnel-like; cauda: elliptic (97.73\%), tubular slightly curved.

Significant differences $(p<0.05)$ were found inside some length classes for otolith shape, anterior region, dorsal and ventral edges, sulcus acusticus morphology and orientation, cauda morphology, otolith profile and rostrum and antirostrum orientation. Over the period of the fishes' development significant differences were obtained in otolith shape, anterior region, dorsal and ventral edge, sulcus acusticus morphology and orientation, cauda orientation, rostrum and antirostrum orientation.

\begin{tabular}{lccc}
\hline Shape indices & Mean \pm SD & Minimum & Maximum \\
\hline OL/TL (\%) & $1.79 \pm 0.23$ & 1.29 & 2.73 \\
OH/OL (\%) & $49.16 \pm 2.65$ & 44.04 & 54.98 \\
OT/OL (\%) & $14.78 \pm 1.42$ & 9.36 & 18.93 \\
OT/OH (\%) & $30.07 \pm 2.51$ & 18.39 & 36.06 \\
Circularity & $27.23 \pm 3.60$ & 20.84 & 37.76 \\
Rectangularity & $0.71 \pm 0.02$ & 0.65 & 0.75 \\
\hline
\end{tabular}

Sardinella brasiliensis (Steindachner 1879) - Plate 3

\begin{tabular}{ll}
\hline Maximum Size: & 240-250 mm (TL) (FIGUEIREDO; MENEZES, 1978; FROESE; PAULY, 2014). \\
Distribution: & Southwestern Atlantic from Rio de Janeiro to Argentina (MENEZES et al., 2003; ESCHEMEYER, 2014). \\
Habitat: & Surface coastal waters. Forms large and compact shoals (FIGUEIREDO; MENEZES, 1978; BERNARDES et al., 2005). \\
Diet: & Zooplankton (FROESE; PAULY, 2014). \\
Collection: & 301 pairs of otoliths (TL ranging from 45 to $264 \mathrm{~mm}$ ). \\
Sample: & 77 left otoliths divided into eleven $20 \mathrm{~mm}$ classes (40 to $240 \mathrm{~mm}$ ). \\
\hline
\end{tabular}

Shape: rectangular to lanceolated (90.91\%), elliptic rectangular, rectangular. Anterior region: lanceolated (90.91\%), peaked. Posterior region: oblique-round (87.19\%), round, blunt-round. Dorsal edge: sinuate to entire (58.44\%), lobed to sinuate, entire. Ventral edge: lobed to entire (49.35\%), dentate to sinuate, dentate to lobed, sinuate to entire. Profile: concave-convex (71.43\%), plane. Rostrum and antirostrum orientation: in agreement (62.34\%), in disagreement. Rostrum: developed. Antirostrum: developed. Sulcus acusticus: position: median; orientation: horizontal (72.73\%), slightly ascending; opening: ostial; morphology: pseudo-archaesulcoid (68.83\%), heterosulcoid; colliculum: heteromorphic; ostium: funnel-like; cauda: elliptic (71.43\%), oval.

Significant differences $(p<0.05)$ were found within some length classes in otolith shape, anterior and posterior regions, dorsal and ventral edges, morphology and orientation of the sulcus acusticus, cauda morphology and otolith profile. During the fishes' development differences were found in otolith shape, anterior and posterior regions, and sulcus acusticus morphology and orientation. 


\begin{tabular}{lccc}
\hline Shape indices & Mean \pm SD & Minimum & Maximum \\
\hline OL/TL (\%) & $2.04 \pm 0.29$ & 1.58 & 2.75 \\
OH/OL (\%) & $45.08 \pm 5.18$ & 36.10 & 65.22 \\
OT/OL (\%) & $14.14 \pm 3.29$ & 8.10 & 25.22 \\
OT/OH (\%) & $31.11 \pm 4.73$ & 20.94 & 43.33 \\
Circularity & $26.31 \pm 3.24$ & 17.29 & 33.04 \\
Rectangularity & $0.69 \pm 0.02$ & 0.65 & 0.73 \\
\hline
\end{tabular}

\section{FAMILY ENGRAULIDAE}

The shape is elliptic, the anterior region is peaked-round, the antirostrum is undeveloped and pseudorostrum and pseudoantirostrum always absent.

Anchoa filifera (Fowler 1915) - Plate 4

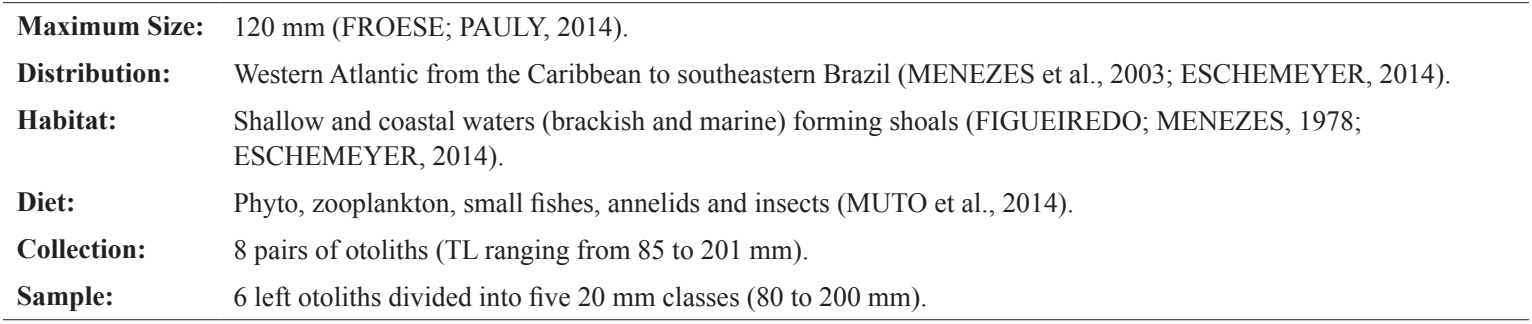

Shape: elliptic. Anterior region: peaked. Posterior region: round (33.33\%), angled (33.33\%), peaked-angled (33.33\%). Dorsal edge: sinuate to entire (66.67\%), sinuate. Ventral edge: sinuate to serrate (83.33\%), lobed to sinuate. Profile: plane-convex (66.67\%), concave-convex. Rostrum and antirostrum orientation: in agreement. Rostrum: developed. Antirostrum: developed (66.67\%), undeveloped. Sulcus acusticus: position: median; orientation: horizontal; opening: ostial; morphology: heterosulcoid; colliculum: heteromorphic; ostium: funnel-like; cauda: elliptic.

The small number of otoliths examined did not permit statistical analysis of the data but their morphometric characteristics are shown below:

\begin{tabular}{lccc}
\hline Shape indices & Mean \pm SD & Minimum & Maximum \\
\hline OL/TL (\%) & $2.82 \pm 0.67$ & 2.03 & 3.56 \\
OH/OL (\%) & $57.36 \pm 3.80$ & 52.08 & 61.39 \\
OT/OL (\%) & $18.85 \pm 2.29$ & 15.80 & 21.19 \\
OT/OH (\%) & $32.80 \pm 2.61$ & 29.36 & 36.16 \\
Circularity & $17.46 \pm 1.15$ & 16.50 & 19.14 \\
Rectangularity & $0.69 \pm 0.02$ & 0.67 & 0.72 \\
\hline
\end{tabular}


Anchoa lyolepis (Evermann \& Marsh 1900) - Plate 5

\begin{tabular}{|c|c|}
\hline Maximum Size: & 120 mm (FROESE; PAULY, 2014). \\
\hline Distribution: & Western Atlantic from Florida to southeastern Brazilian coast (MENEZES et al., 2003; ESCHEMEYER, 2014). \\
\hline Habitat: & Coastal waters (ESCHEMEYER, 2014). Forms shoals. Depth range: 1 - 54 m (FROESE; PAULY, 2014). \\
\hline Diet: & Plankton (FROESE; PAULY, 2014). \\
\hline Collection: & 17 pairs of otoliths (TL ranging from 59 to $93 \mathrm{~mm}$ ). \\
\hline Sample: & 4 left otoliths divided into three $20 \mathrm{~mm}$ classes ( 40 to $80 \mathrm{~mm}$ ). \\
\hline
\end{tabular}

Shape: elliptic. Anterior region: peaked. Posterior region: round. Dorsal edge: sinuate to entire (50\%), sinuate, entire. Ventral edge: sinuate to entire (50\%), sinuate to serrate (50\%). Profile: plane-convex (75\%), concave-convex. Rostrum and antirostrum orientation: in agreement. Rostrum: developed. Antirostrum: undeveloped (75\%), absent. Sulcus acusticus: position: median; orientation: horizontal; opening: ostial; morphology: heterosulcoid; colliculum: heteromorphic; ostium: funnel-like; cauda: elliptic.

The small number of otoliths examined did not permit the statistical analysis of the data but their morphometric characteristics are shown below:

\begin{tabular}{lccc}
\hline Shape indices & Mean \pm SD & Minimum & Maximum \\
\hline OL/TL (\%) & $3.04 \pm 0.18$ & 2.91 & 3.30 \\
OH/OL (\%) & $53.23 \pm 2.88$ & 50.64 & 56.07 \\
OT/OL (\%) & $20.95 \pm 0.95$ & 20.09 & 22.03 \\
OT/OH (\%) & $39.44 \pm 2.58$ & 36.08 & 42.37 \\
Circularity & $16.62 \pm 0.50$ & 16.04 & 17.24 \\
Rectangularity & $0.72 \pm 0.01$ & 0.70 & 0.74 \\
\hline
\end{tabular}

Anchoa tricolor (Spix \& Agassiz 1829) - Plate 6

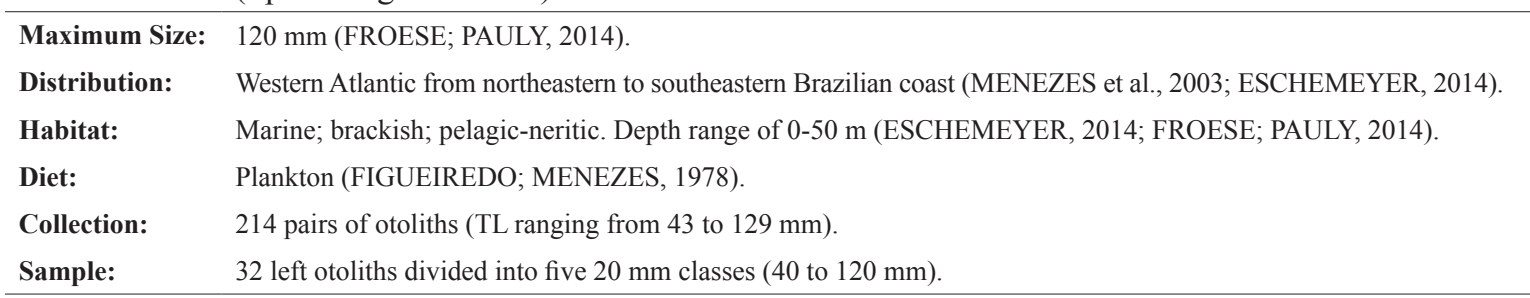

Shape: elliptic. Anterior region: peaked (78.13\%), peaked-round, angled. Posterior region: round (65.63\%), angled-round. Dorsal edge: entire (56.25\%), sinuate. Ventral edge: sinuate to entire (34.38\%), sinuate to serrate, sinuate, entire to serrate. Profile: flattened (40.63\%), concave-convex, plane-convex. Rostrum and antirostrum orientation: in agreement (84.38\%), except when the antirostrum is undeveloped or absent. Rostrum: developed. Antirostrum: developed (56.25\%), undeveloped, absent. Sulcus acusticus: position: median; orientation: horizontal; opening: ostial; morphology: heterosulcoid; colliculum: heteromorphic; ostium: funnel-like; cauda: elliptic.

Significant differences $(p<0.05)$ were found within some length classes in anterior and posterior regions, dorsal edge, otolith profile, rostrum and antirostrum orientation and antirostrum development. Over the period of the fishes' development differences were found only in the posterior region of the otoliths. 


\begin{tabular}{lccc}
\hline Shape indices & Mean \pm SD & Minimum & Maximum \\
\hline OL/TL (\%) & $2.75 \pm 0.28$ & 2.17 & 3.52 \\
OH/OL (\%) & $59.81 \pm 4.43$ & 49.39 & 67.27 \\
OT/OL (\%) & $20.22 \pm 1.92$ & 16.36 & 24.55 \\
OT/OH (\%) & $33.79 \pm 1.74$ & 29.93 & 36.99 \\
Circularity & $17.48 \pm 1.43$ & 15.10 & 21.82 \\
Rectangularity & $0.70 \pm 0.02$ & 0.66 & 0.74 \\
\hline
\end{tabular}

Anchovia clupeoides (Swainson 1839) - Plate 7

\begin{tabular}{|c|c|}
\hline Maximum Size: & 300 mm (FROESE; PAULY, 2014). \\
\hline Distribution: & Western Atlantic from the Caribbean to São Paulo state, Brazil (MENEZES et al., 2003; ESCHEMEYER, 2014). \\
\hline Habitat: & Marine; brackish; benthopelagic (ESCHEMEYER, 2014; FROESE; PAULY, 2014). \\
\hline Diet: & Plankton (CARPENTER, 2002). \\
\hline Collection: & 23 pairs of otoliths (TL ranging from 55 to $80 \mathrm{~mm}$ ). \\
\hline Sample: & 10 left otoliths divided into two $20 \mathrm{~mm}$ classes ( 40 to $60 \mathrm{~mm}$ ). \\
\hline
\end{tabular}

Shape: elliptic. Anterior region: peaked. Posterior region: round (90\%), oblique-round. Dorsal edge: sinuate to entire. Ventral edge: sinuate to serrate (70\%), lobed to sinuate, sinuate. Profile: biconvex. Rostrum and antirostrum orientation: in agreement. Rostrum: developed. Antirostrum: developed (50\%), undeveloped (50\%). Sulcus acusticus: position: median; orientation: horizontal; opening: ostial; morphology: heterosulcoid (80\%), pseudo-archaesulcoid; colliculum: heteromorphic; ostium: funnel-like; cauda: elliptic.

Significant differences $(p<0.05)$ were observed in some length classes in the anterior region, ventral edge and sulcus acusticus morphology. During the fishes' development differences were observed only for the anterior region of these structures.

\begin{tabular}{lccc}
\hline Shape indices & Mean \pm SD & Minimum & Maximum \\
\hline OL/TL (\%) & $3.67 \pm 0.28$ & 3.26 & 4.27 \\
OH/OL (\%) & $61.30 \pm 1.66$ & 58.76 & 64.36 \\
OT/OL (\%) & $23.23 \pm 1.88$ & 19.71 & 26.32 \\
OT/OH (\%) & $37.91 \pm 3.23$ & 31.95 & 44.30 \\
Circularity & $16.61 \pm 0.82$ & 15.78 & 18.36 \\
Rectangularity & $0.70 \pm 0.02$ & 0.68 & 0.74 \\
\hline
\end{tabular}

Anchoviella lepidentostole (Fowler 1911) - Plate 8

\begin{tabular}{|c|c|}
\hline Maximum Size: & 120 mm (FROESE; PAULY, 2014). \\
\hline Distribution: & Western Atlantic from the Guianas to the southeastern Brazilian coast (MENEZES et al., 2003; ESCHEMEYER, 2014). \\
\hline Habitat: & Freshwater, brackish, marine. Depth range of 0 - 50 m (ESCHEMEYER, 2014; FROESE; PAULY, 2014). \\
\hline Diet: & Crustacean larvae or small invertebrates (FROESE; PAULY, 2014). \\
\hline Collection: & 54 pairs of otoliths (TL ranging from 72 to $126 \mathrm{~mm}$ ). \\
\hline Sample: & 17 left otoliths divided into four $20 \mathrm{~mm}$ classes (60 to $120 \mathrm{~mm}$ ). \\
\hline
\end{tabular}


Shape: elliptic. Anterior region: peaked (76.47\%), peaked-round. Posterior region: angled-round (47.06\%), peaked, round, angled. Dorsal edge: sinuate to entire (52.94\%), entire, sinuate. Ventral edge: entire to serrate (88.24\%), sinuate to serrate. Profile: concave-convex (70.59\%), plane-convex. Rostrum and antirostrum orientation: in agreement. Rostrum: developed. Antirostrum: developed (70.59\%), undeveloped. Sulcus acusticus: position: median; orientation: horizontal; opening: ostial; morphology: heterosulcoid (94.12\%), pseudo-archaesulcoid; colliculum: heteromorphic; ostium: funnellike; cauda: elliptic.

Significant differences $(p<0.05)$ were observed in some length classes in the dorsal edge and the sulcus acusticus morphology. No differences were found during the fishes' development.

\begin{tabular}{lccc}
\hline Shape indices & Mean \pm SD & Minimum & Maximum \\
\hline OL/TL (\%) & $2.72 \pm 0.12$ & 2.51 & 2.93 \\
OH/OL (\%) & $58.03 \pm 3.41$ & 52.26 & 62.46 \\
OT/OL (\%) & $18.89 \pm 1.08$ & 16.73 & 20.74 \\
OT/OH (\%) & $32.60 \pm 1.61$ & 30.05 & 35.48 \\
Circularity & $18.08 \pm 0.59$ & 16.94 & 19.37 \\
Rectangularity & $0.67 \pm 0.01$ & 0.65 & 0.69 \\
\hline
\end{tabular}

Cetengraulis edentulus (Cuvier 1829) - Plate 9

\begin{tabular}{|c|c|}
\hline Maximum Size: & 150 mm (FROESE; PAULY, 2014). \\
\hline Distribution: & Central and Southwestern Atlantic along the entire Brazilian coast (MENEZES et al., 2003; ESCHEMEYER, 2014). \\
\hline Habitat: & $\begin{array}{l}\text { Occurs inshore and forms quite large schools. Enters brackish waters of lagoons and estuaries (ESCHEMEYER, } \\
\text { 2014; FROESE; PAULY, 2014). }\end{array}$ \\
\hline Diet: & Filter-feeder presumably on both phytoplankton and zooplankton (FROESE; PAULY, 2014). \\
\hline Collection: & 38 pairs of otoliths (TL ranging from 78 to $93 \mathrm{~mm}$ ). \\
\hline Sample: & 32 left otoliths divided into two $20 \mathrm{~mm}$ classes ( 60 to $80 \mathrm{~mm}$ ). \\
\hline
\end{tabular}

Shape: elliptic. Anterior region: peaked round (63.64\%), angled-round. Posterior region: angled (54.55\%), angledround, peaked, round. Dorsal edge: sinuate to entire (45\%), sinuate (45\%), entire. Ventral edge: entire to serrate (63.64\%), sinuate to serrate. Profile: plane-convex (90.91\%), concave-convex. Rostrum and antirostrum orientation: in agreement. Rostrum: developed. Antirostrum: developed (90.91\%), undeveloped. Sulcus acusticus: position: median; orientation: horizontal; opening: ostial; morphology: heterosulcoid (90.91\%), pseudo-archaesulcoid; colliculum: heteromorphic; ostium: elliptic; cauda: elliptic.

Significant differences $(p<0.05)$ were found in some length classes in the posterior region of the otolith, in the sulcus acusticus morphology and the antirostrum development. During the fishes' development differences were present only in the anterior region of these structures.

\begin{tabular}{lccc}
\hline Shape indices & Mean \pm SD & Minimum & Maximum \\
\hline OL/TL (\%) & $2.85 \pm 0.25$ & 2.46 & 3.35 \\
OH/OL (\%) & $67.24 \pm 2.55$ & 63.49 & 70.54 \\
OT/OL (\%) & $20.88 \pm 1.77$ & 18.01 & 23.36 \\
OT/OH (\%) & $31.03 \pm 2.14$ & 26.86 & 34.97 \\
Circularity & $17.04 \pm 0.56$ & 16.20 & 18.31 \\
Rectangularity & $0.68 \pm 0.01$ & 0.66 & 0.70 \\
\hline
\end{tabular}


Engraulis anchoita Hubbs \& Marini 1935 - Plate 10

\begin{tabular}{|c|c|}
\hline Maximum Size: & 170 mm (SL) (FROESE; PAULY, 2014). \\
\hline Distribution: & Southwestern Atlantic from Rio de Janeiro (Brazil) to Argentina (MENEZES et al., 2003; ESCHEMEYER, 2014). \\
\hline Habitat: & $\begin{array}{l}\text { Marine. Dense shoals at } 30 \text { to 200m deep (ESCHEMEYER, 2014). Exhibits north-south and near shore-offshore } \\
\text { migrations (FROESE; PAULY, 2014). }\end{array}$ \\
\hline Diet: & Juveniles feed on phytoplankton but zooplankton become increasingly important as fish grow (FROESE; PAULY, 2014). \\
\hline Collection: & 3444 pairs of otoliths (TL ranging from 38 to $165 \mathrm{~mm}$ ). \\
\hline Sample: & 62 left otoliths divided into seven $20 \mathrm{~mm}$ classes (40 to $160 \mathrm{~mm}$ ). \\
\hline
\end{tabular}

Shape: elliptic (69.35\%), fusiform, discoidal, discoidal to elliptic. Anterior region: peaked (91.94\%), angled-round, peaked-round. Posterior region: angled-round (41.94\%), round, peaked, peaked-round, angled-round. Dorsal edge: entire (48.39\%), sinuate, sinuate to entire. Ventral edge: entire to serrate $(69.35 \%)$, sinuate to serrate, sinuate to entire, lobed to entire. Profile: concave-convex (67.74\%), plane-convex, flattened, biconvex. Rostrum and antirostrum orientation: in agreement (87.10\%). Rostrum: developed. Antirostrum: developed (59.68\%), undeveloped, absent. Sulcus acusticus: position: median; orientation: horizontal; opening: ostial; morphology: heterosulcoid; colliculum: heteromorphic; ostium: funnel-like (77.42\%), elliptic; cauda: elliptic.

In some length classes significant differences $(p<0.05)$ were observed for the otolith shape, anterior and posterior regions, ventral edge, ostium morphology, otolith profile, rostrum and antirostrum orientation and antirostrum development. During the fishes' development differences were found in the posterior region and in the ventral edge of the otoliths.

\begin{tabular}{lccc}
\hline Shape indices & Mean \pm SD & Minimum & Maximum \\
\hline OL/TL (\%) & $2.73 \pm 0.47$ & 1.65 & 4.56 \\
OH/OL (\%) & $55.60 \pm 7.35$ & 45.80 & 84.51 \\
OT/OL (\%) & $18.40 \pm 2.77$ & 13.49 & 29.58 \\
OT/OH (\%) & $33.10 \pm 2.56$ & 29.14 & 40.54 \\
Circularity & $18.14 \pm 1.33$ & 14.42 & 22.43 \\
Rectangularity & $0.68 \pm 0.02$ & 0.64 & 0.74 \\
\hline
\end{tabular}

\section{FAMILY PRISTIGASTERIDADE}

The anterior region is peaked. The ostium and cauda are always elliptic, and in most otoliths the sulcus acusticus is pseudo-archaesulcoid, and pseudorostrum and pseudoantirostrum: always absent.

Chirocentrodon bleekerianus (Poey 1867) - Plate 11

\begin{tabular}{ll}
\hline Maximum Size: & $110 \mathrm{~mm}$ (TL) (FIGUEIREDO; MENEZES, 1978; FROESE; PAULY, 2014). \\
$\begin{array}{l}\text { Distribution: } \\
\text { Habitat: }\end{array}$ & Western Atlantic from Panama to São Paulo, Brazil (MENEZES et al., 2003; ESCHEMEYER, 2014). \\
Diet: & Zooplankton and small fishes (MUTO et al., 2008). \\
Collection: & 330 pairs of otoliths (TL ranging from 65 to $128 \mathrm{~mm})$. \\
Sample: & 30 left otoliths divided into three $20 \mathrm{~mm}$ classes $(60$ to $100 \mathrm{~mm})$. \\
\hline
\end{tabular}


Shape: elliptic. Anterior region: peaked. Posterior region: round. Dorsal edge: sinuate to entire (70\%), entire, sinuate. Ventral edge: serrate to entire. Profile: biconvex. Rostrum and antirostrum orientation: in agreement. Rostrum: developed. Antirostrum: underdeveloped. Sulcus acusticus: position: median; orientation: horizontal (93.33\%), slightly ascending; opening: ostial (73.33\%), pseudo-ostial; morphology: pseudo-archaesulcoid; colliculum: heteromorphic; ostium: elliptic; cauda: elliptic.

Significant differences $(p<0.05)$ were found in some length classes for the posterior region, dorsal edge, sulcus acusticus orientation and opening, and antirostrum development. During the fishes' ontogeny significant differences were observed for the posterior region, sulcus acusticus orientation and opening and antirostrum development.

\begin{tabular}{lccc}
\hline Shape indices & Mean \pm SD & Minimum & Maximum \\
\hline OL/TL (\%) & $2.38 \pm 0.35$ & 1.98 & 3.49 \\
OH/OL (\%) & $69.96 \pm 4.44$ & 61.99 & 77.01 \\
OT/OL (\%) & $20.23 \pm 1.79$ & 16.87 & 24.62 \\
OT/OH (\%) & $29.01 \pm 2.94$ & 24.44 & 35.76 \\
Circularity & $17.66 \pm 0.95$ & 15.85 & 19.39 \\
Rectangularity & $0.69 \pm 0.02$ & 0.62 & 0.72 \\
\hline
\end{tabular}

\section{Pellona harroweri (Fowler 1917) - Plate 12}

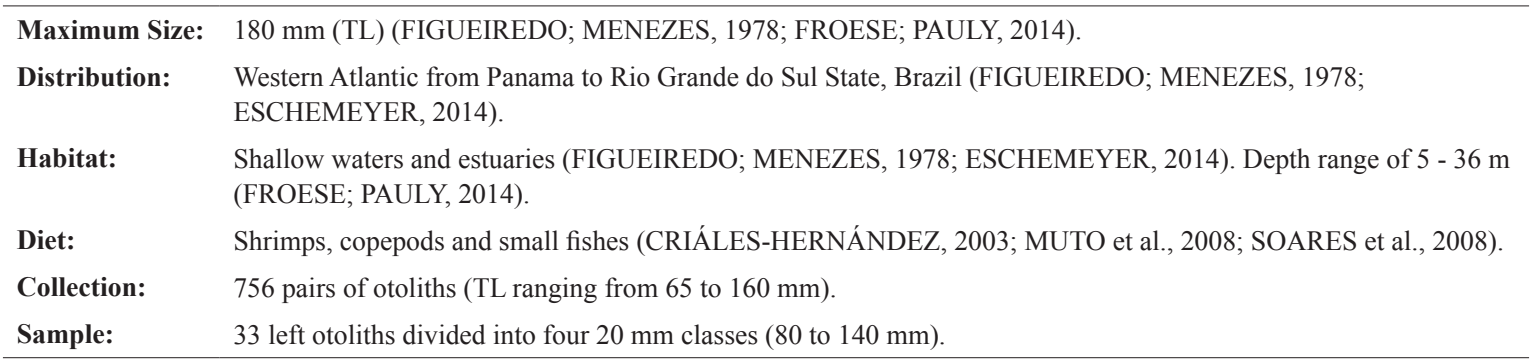

Shape: elliptic. Anterior region: peaked. Posterior region: round. Dorsal edge: sinuate to entire (93.94\%), lobed. Ventral edge: dentate to entire (90.91\%), dentate to sinuate. Profile: concave-convex. Rostrum and antirostrum orientation: in agreement. Rostrum: developed. Antirostrum: developed. Sulcus acusticus: position: median; orientation: horizontal; opening: ostial (93.94\%), pseudo-ostial; morphology: pseudo-archaesulcoid (63.64\%), heterosulcoid; colliculum: heteromorphic; ostium: elliptic; cauda: elliptic.

Significant differences $(p<0.05)$ were found in some total length classes for the dorsal and ventral edges, and sulcus acusticus morphology and opening. No differences were observed during the fishes' development.

\begin{tabular}{lccc}
\hline Shape indices & Mean \pm SD & Minimum & Maximum \\
\hline OL/TL (\%) & $3.22 \pm 0.27$ & 2.74 & 3.74 \\
OH/OL (\%) & $66.92 \pm 2.93$ & 61.96 & 77.17 \\
OT/OL (\%) & $19.89 \pm 1.59$ & 17.06 & 24.76 \\
OT/OH (\%) & $29.72 \pm 2.08$ & 25.97 & 34.22 \\
Circularity & $19.52 \pm 1.09$ & 17.84 & 21.99 \\
Rectangularity & $0.69 \pm 0.01$ & 0.66 & 0.72 \\
\hline
\end{tabular}




\section{ACKNOWLEDGMENTS}

The organization of the collection and the analysis of the otoliths began five years ago when substantial financial support was received from the Fundação de Amparo à Pesquisa do Estado de São Paulo (FAPESP Processes -2010/516312 and 2014/03764-4) which permitted the improvement of the laboratory and its equipment and the addition of human resources to the LABIC. The authors wish to express their gratitude to everyone who participated in this long process. In relation to this volume special thanks are due to Silvia de Almeida Gonsales, Marcella Bockis Giaretta and Alexandre Y. Gomes Arackawa for their drawings, measurements of the otoliths and organization of the collection.

Special thanks also to Dr. Carlos A. Assis and the anonymous referee for their valuable comments which greatly improved this paper.

\section{REFERENCES}

BERNARDES, R. A.; FIGUEIREDO, J. L.; RODRIGUES, A. R.; FISCHER, L. G.; VOOREN, C. M.; HAIMOVICI, M.; ROSSIWONGTSCHOWSKI, C. L. D. B. Peixes da Zona Exclusiva da região Sudeste-Sul do Brasil: levantamento com armadilhas, pargueiras e rede de arrasto de fundo. São Paulo: EDUSP, 2005. 304 p.

CARPENTER, K. E. The living marine resources of the Western Central Atlantic. Volume 2: Bony Fishes part 2 (Opistognathidae to Molidae), sea turtles and marine mammals. FAO Species Identification Guide for Fishery Purposes and American Society of Ichthyologists and Herpetologists Special Publication N. 5. Rome: FAO; 2002. p. 1375-2127.

CRIALES-HERNÁNDEZ, M. I. Composición de la dieta Pellona harroweri (Fowler) (Pisces: Pristigasteridae) en la Guajira, Caribe Colombiano. Santa Marta, Colombia. Bol. Invest. Mar. Cost., v. 32, n. 1, p. 279-282, 2003.

ESCHMEYER, W. N. Catalog of fishes: genera, species, references. Available at: < http://research.calacademy.org/research/ichthyology/ catalog/fishcatmain.asp>. Accessed: 4 June 2014

FIGUEIREDO, J. L.; MENEZES, N. A. Manual dos peixes marinhos do Sudeste do Brasil. II. Teleostei (1). São Paulo: Museu de Zoologia da USP, 1978. $110 \mathrm{p}$.

FROESE, R.; PAULY. D. FishBase. World Wide Web electronic publication, version 2014. Available at: <http://www.fishbase.org> Accessed: 08/2014.

FURTADO-OGAWA, E. Alimentação da sardinha-bandeira, Opisthonema oglinum (LLE SUEUR) no estado do Ceará. Arq. Ciênc Mar., v. 10, n. 2, p. 201-202, 1970.

MENEZES, N. A.; FIGUEIREDO, J. L. Family Engraulidae. In: MENEZES, N. A.; BUCKUP, P. A.; FIGUEIREDO, J. L.; MOURA, R. L. (Eds.). Catálogo das espécies de peixes marinhos do Brasil. São Paulo: Museu de Zoologia da Universidade de São Paulo, 2003.160 p.

MUTO, E. Y.; CORBISIER, T. N.; COELHO, L. I.; ARANTES, L. P. L.; CHALOM, A.; SOARES, L. S. H. Trophic groups of demersal fish of Santos Bay and adjacent continental shelf, São Paulo State, Brazil: temporal and spatial comparisons. Braz. J. Oceanogr., v. 62, n. 2, p. 89-102, 2014.

MUTO, E. Y.; MALFARA, D. T.; COELHO, L. I.; SOARES, L. S. H. Alimentação das sardinhas Pellona harroweri (Fowler, 1919) e Chirocentrodon bleekerianus (Poey, 1867), na região costeira de Santos, Estado de São Paulo. In: BRAGA, E.S. (Org.). Oceanografia e mudanças globais. São Paulo: Instituto Oceanográfico, 2008. p. 287-302.

ROSSI-WONGTSCHOWSKI, C. L. D. B.; SILIPRANDI, C. C.; BRENHA, M. R.; GONSALES, S. A.; SANTIFICETUR, C.; VAZDOS-SANTOS, A. M. Atlas of marine bony fish otoliths (sagittae) of Southeastern-southern Brazil. Part I: Gadiformes (Macrouridae, Moridae, Bregmacerotidae, Phycidae and Merlucciidae); Part II: Perciformes (Carangidae, Sciaenidae, Scombridae and Serranidae). Braz. J. Oceanogr., v. 62, no.spe1, p. 1-103, 2014.

SOARES, L. S. H.; MUTO, E.; GASPARRO, M. R.; ROSSI-WONGTSCHOWSKI, C. L. D. B. Organização trófica dos peixes. In: PIRES-VANIN, A. M. S. (Org.). Oceanografia de um ecossistema subtropical: plataforma de São Sebastião. São Paulo: EDUSP, 2008 p. 406-425. 
A1

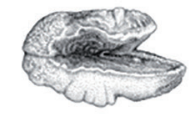

A2

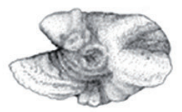

A3

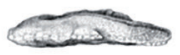

\section{$1 \mathrm{~mm}$}

B1

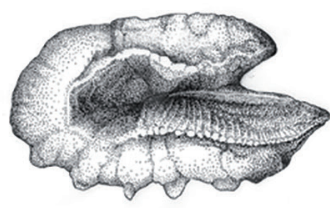

B2

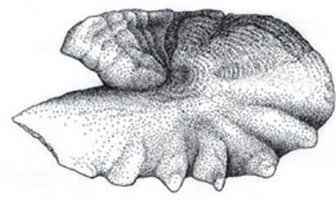

B3

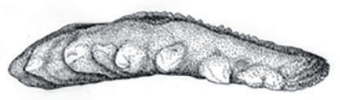

C1

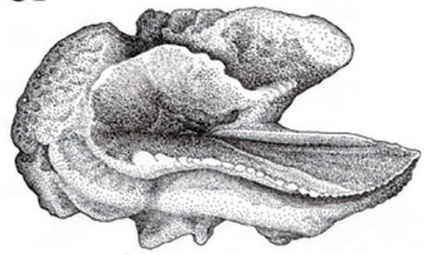

C2

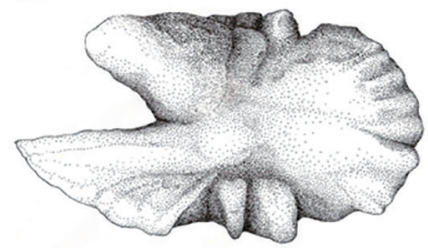

C3

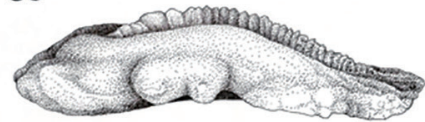

\section{$\longmapsto$}

$1 \mathrm{~mm}$

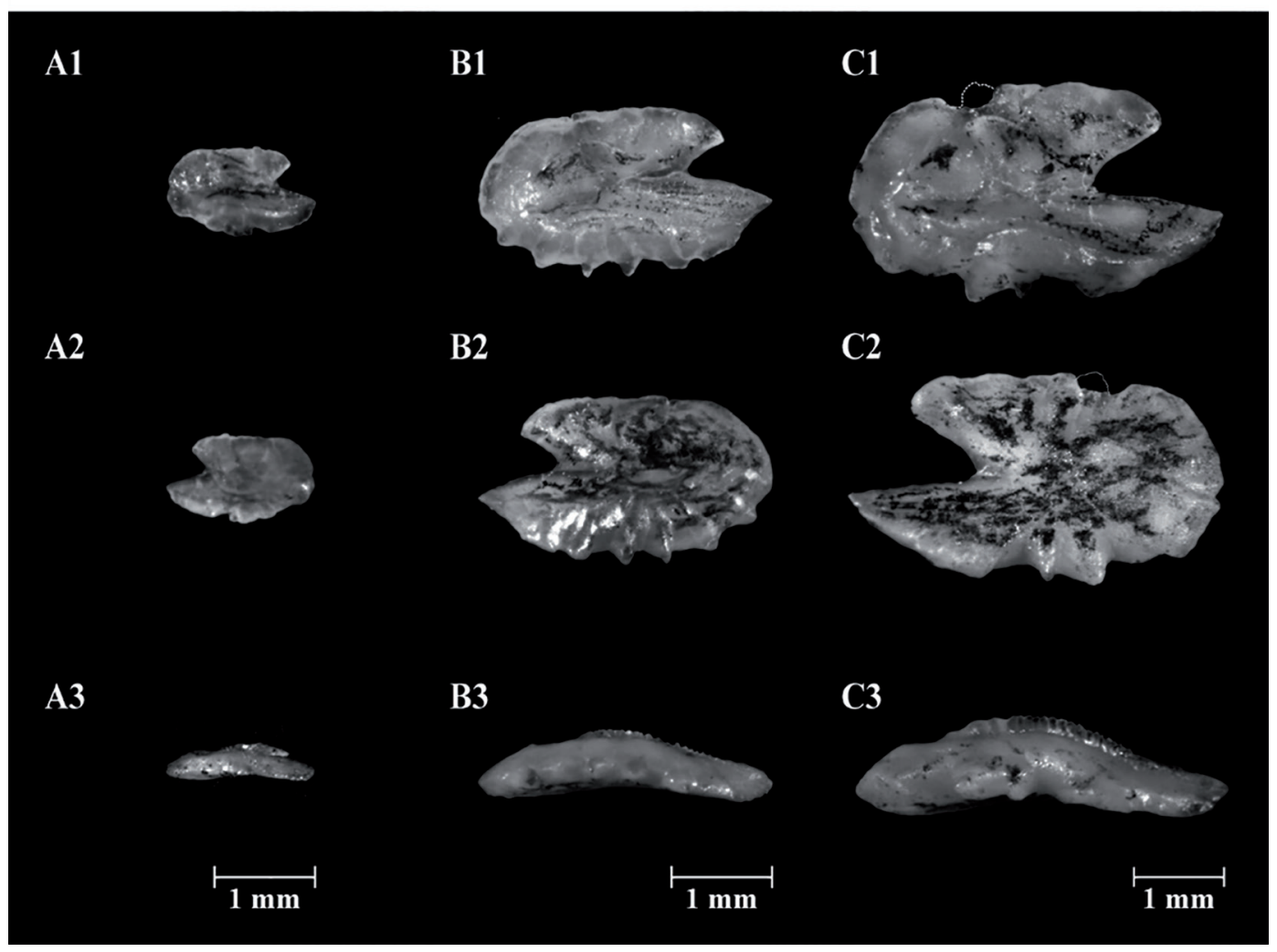

Plate 1. Illustrations (above) and photographs (below) of Harengula clupeola otoliths from fishes with total lengths: A. 65 mm; B. $128 \mathrm{~mm}$; C. $190 \mathrm{~mm}$. The medial face is shown in A1, B1, C1; the lateral face in A2, B2, C2; and the ventral profile in A3, B3, C3 (Illustration: Silvia de Almeida Gonsales; Photos: Cesar Santificetur). 
A1

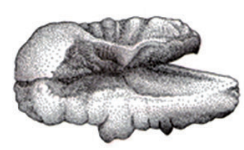

A2

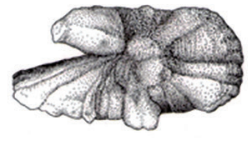

A3

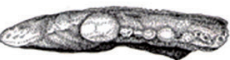

B1

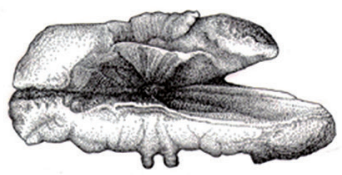

B2

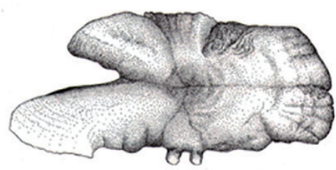

B3

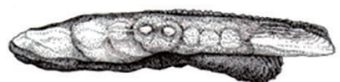

C1

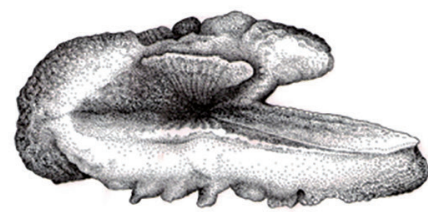

C2

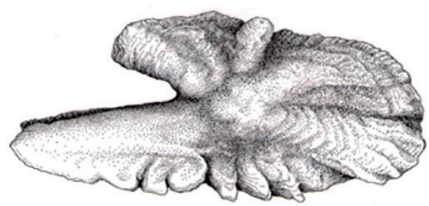

C3

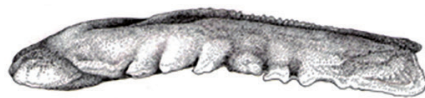

A1

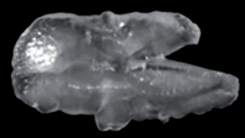

A2

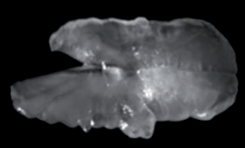

$\stackrel{\longmapsto}{1 \mathrm{~mm}}$

B1

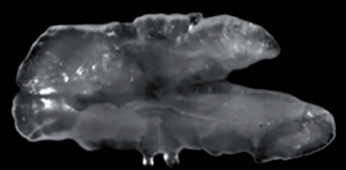

B2

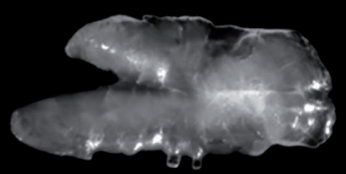

\section{C1}

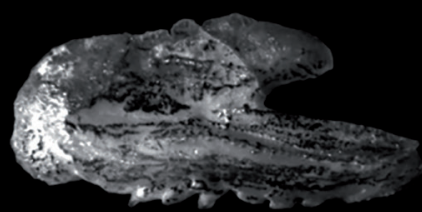

C2

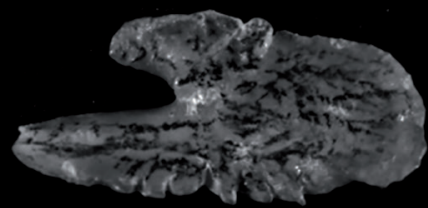

A3

cos.t.
B3

$\stackrel{\mathrm{mm}}{1 \mathrm{~m}}$

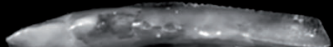

C3

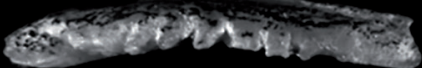


A1

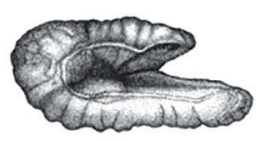

A2

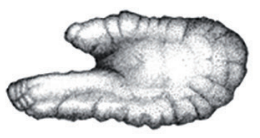

A3

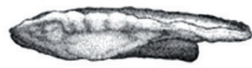

B1

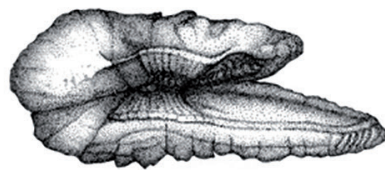

B2

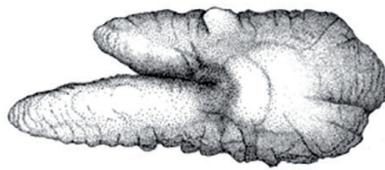

B3

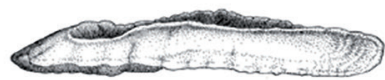

C1

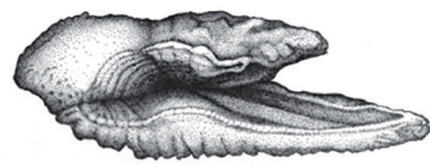

C2

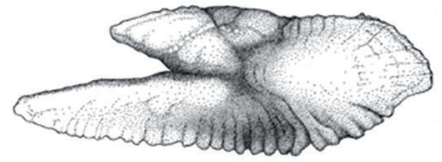

C3

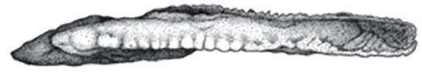

$\longmapsto$

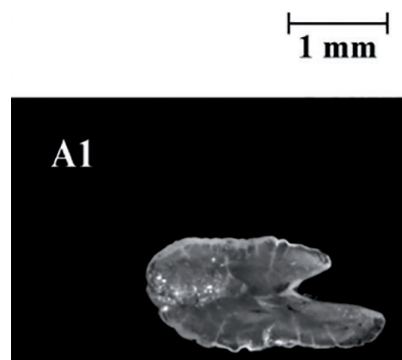

A2

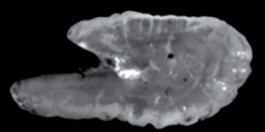

B1

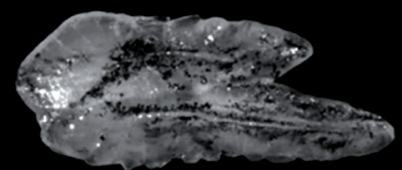

B2

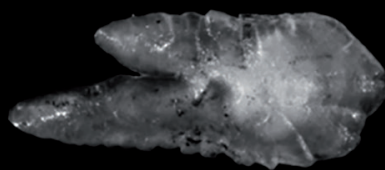

C1

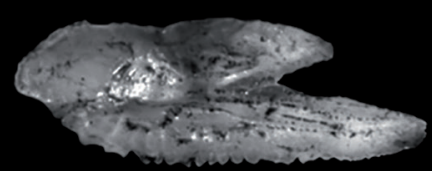

C2

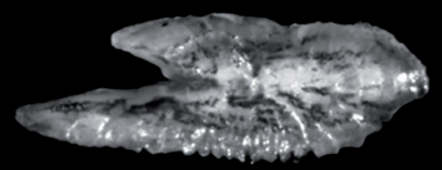

A3

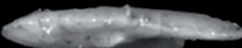

B3

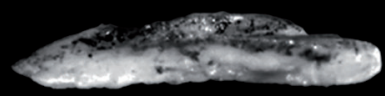

\section{$1 \mathrm{~mm}$}


A1

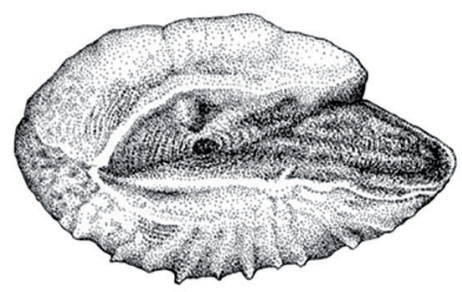

A2

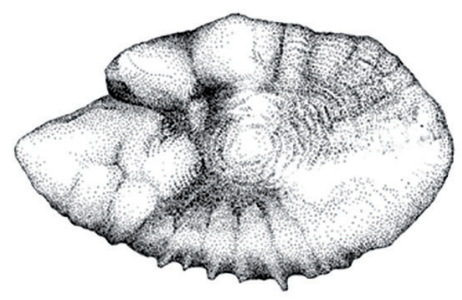

A3

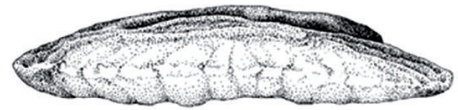

$\longmapsto$

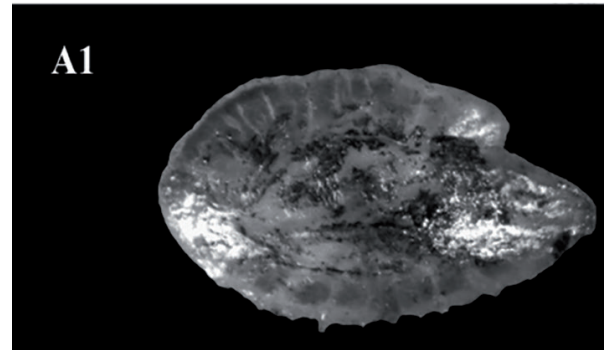

A2

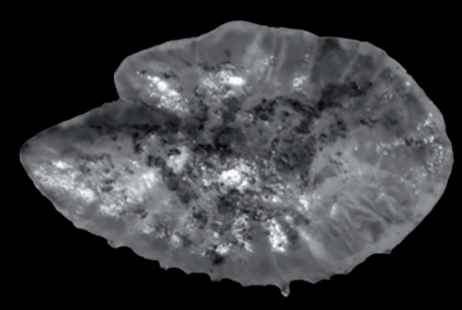

A3

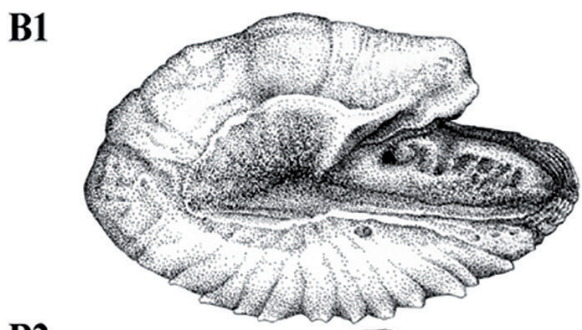

B2

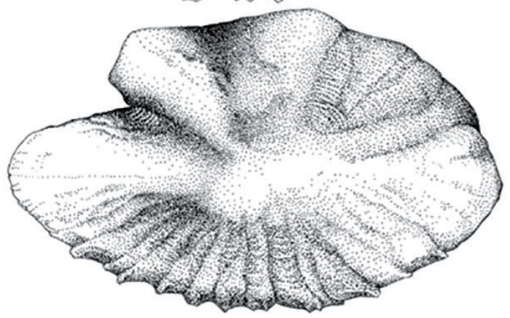

B3

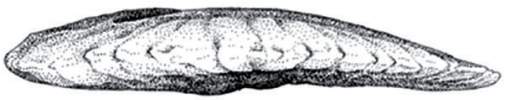

$1 \mathrm{~mm}$ 
A1

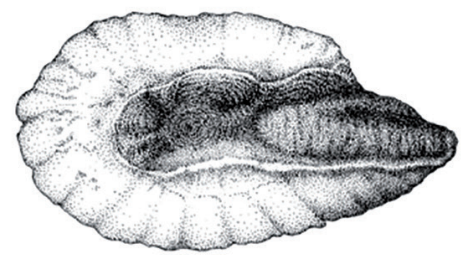

A2

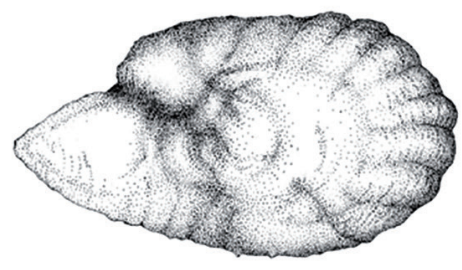

A3

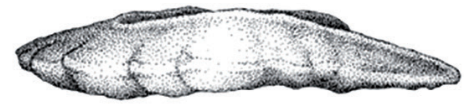

\section{$1 \mathrm{~mm}$}

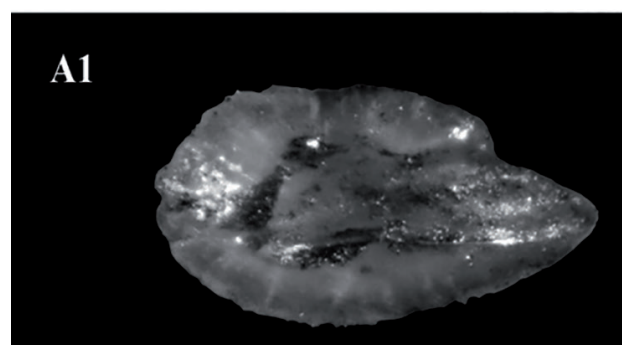

A2

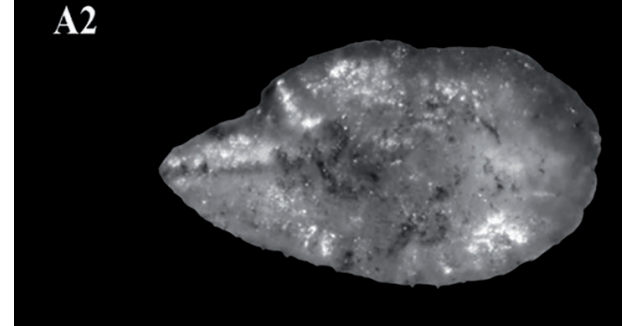

A3
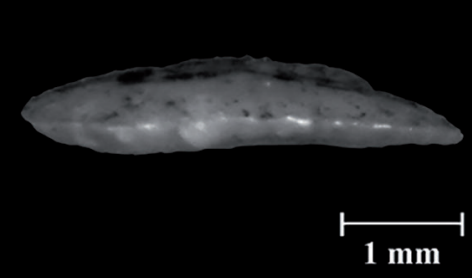

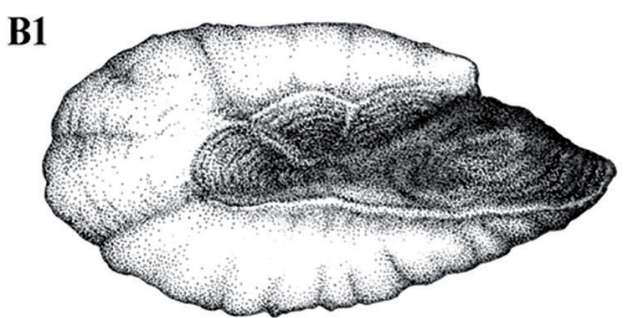

B2

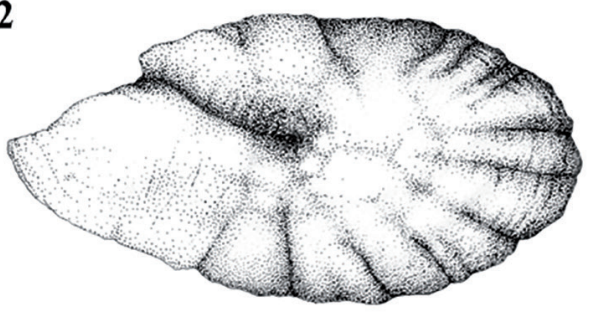

B3

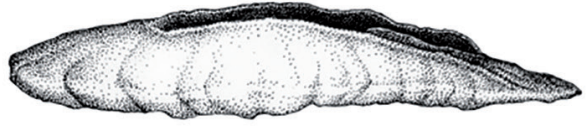

$\stackrel{1 \mathrm{~mm}}{1 \mathrm{~m}}$

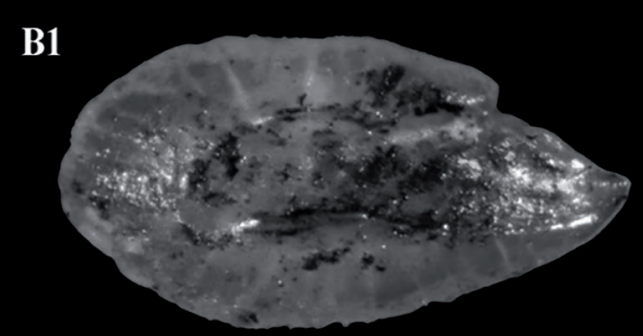

B2

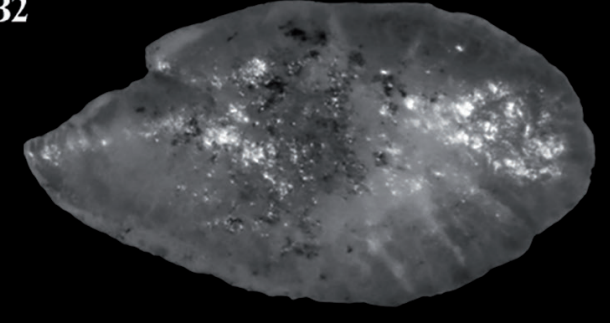

B3

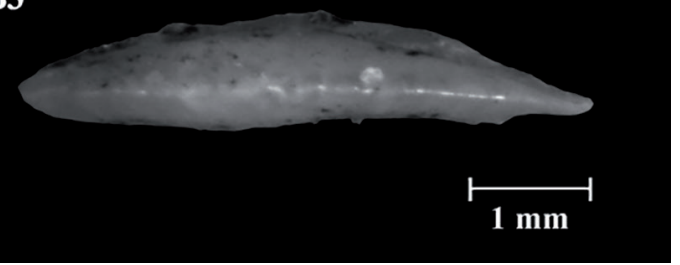

Plate 5. Illustrations (above) and photographs (below) of Anchoa lyoleps otoliths from fishes with total lengths: A. 59 mm; B. 80 $\mathrm{mm}$. The medial face is shown in A1, B1; the lateral face in A2, B2; the ventral profile in A3, B3 (Illustration: Alexandre Arackawa; Photos: Alexandre Arackawa). 
A1

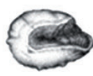

A2

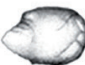

A3
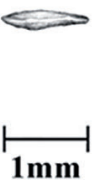

B1

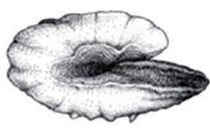

B2

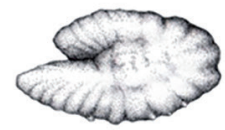

B3
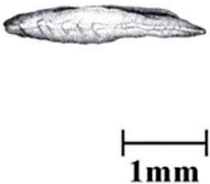

C1

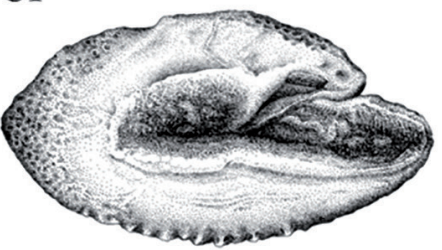

C2

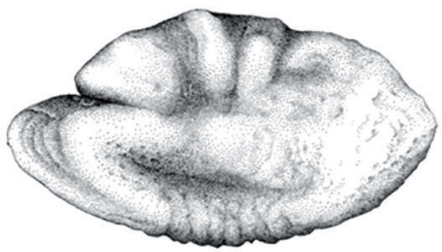

C3

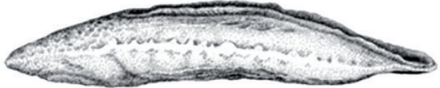

A1

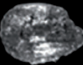

A2

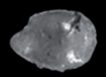

A3

C.sen

$\mathrm{C}=\mathrm{m}$

B2

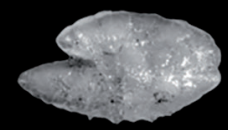

B1

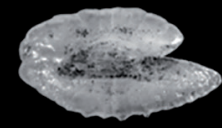

C1

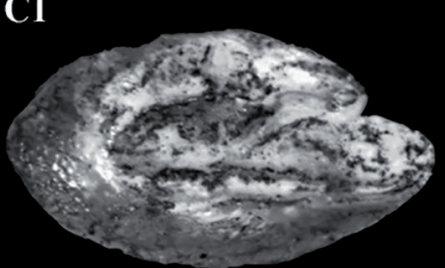

C2

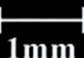

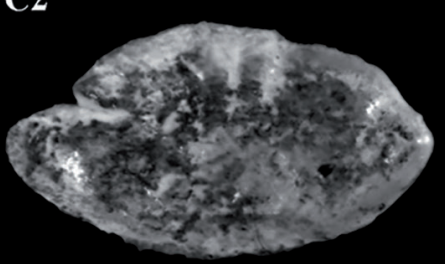

C3

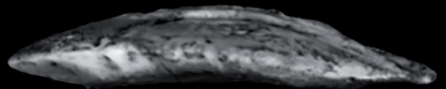

Plate 6. Illustrations (above) and photographs (below) of Anchoa tricolor from fishes with total lengths: A. $43 \mathrm{~mm}$; B.86 mm; C. $129 \mathrm{~mm}$. The medial face is shown in A1, B1, C1; the lateral face in A2, B2, C2; and the ventral profile in A3, B3, C3 (Illustration: Alexandre Arackawa; Photos: Cesar Santificetur). 
A1

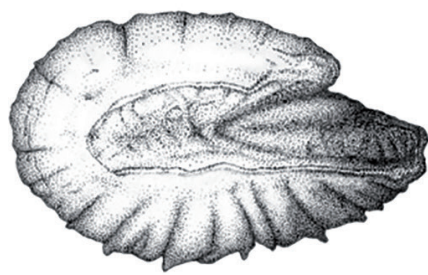

A2

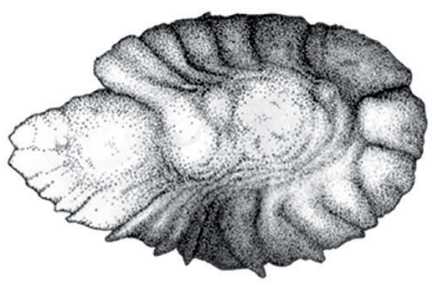

A3
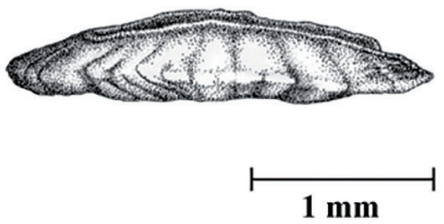

B1

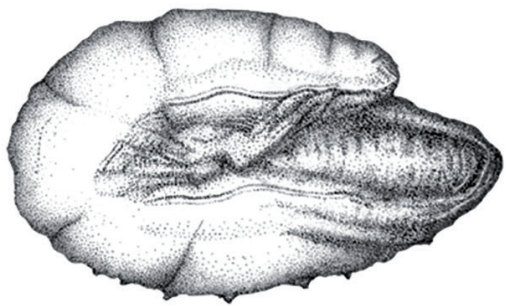

B2

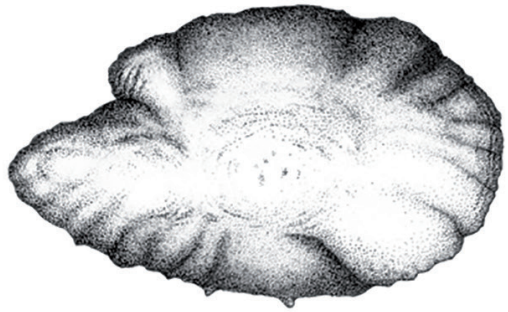

B3

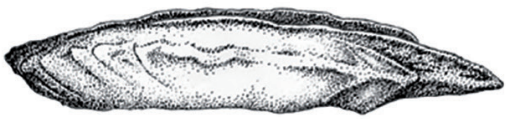

$1 \mathrm{~mm}$

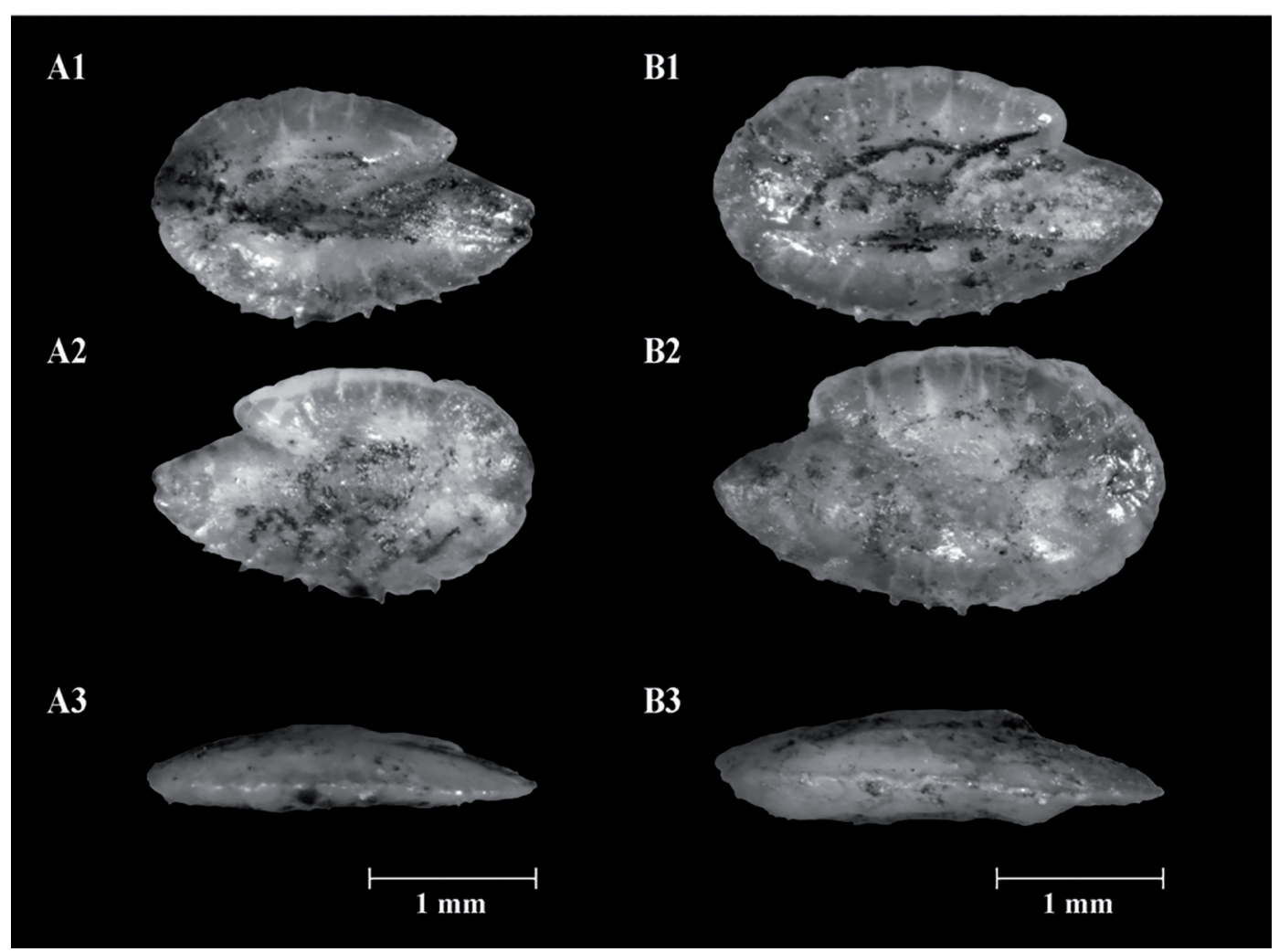

Plate 7. Illustrations (above) and photographs (below) of Anchovia clupeoides otoliths from fish with total lengths: A. 55 mm; B. $80 \mathrm{~mm}$. The medial face is shown in A1, B1; the lateral face in A2, B2; and the ventral profile in A3, B3 (Illustration: Alexandre Arackawa; Photos: Alexandre Arackawa). 
A1

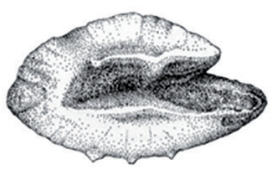

A2

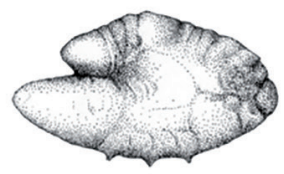

A3
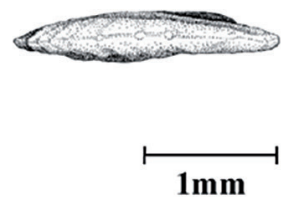

B1

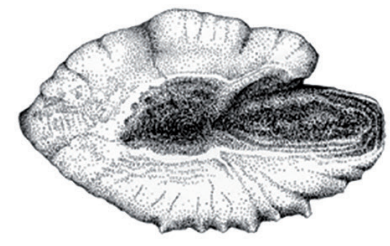

B2

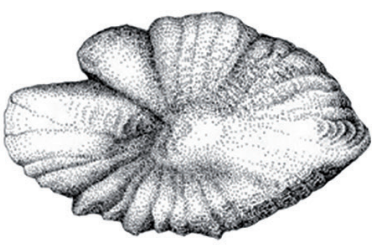

B3

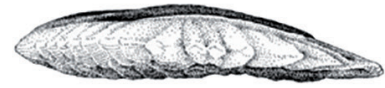

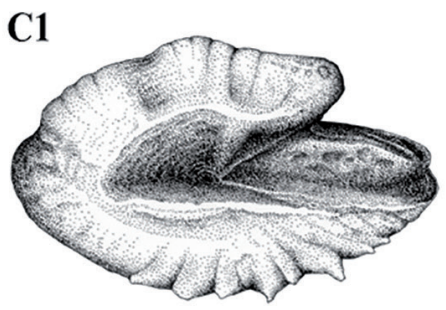

$\mathrm{C} 2$

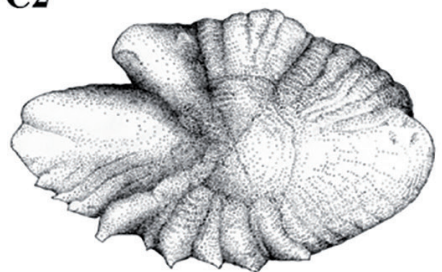

C3

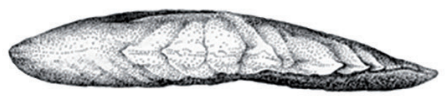

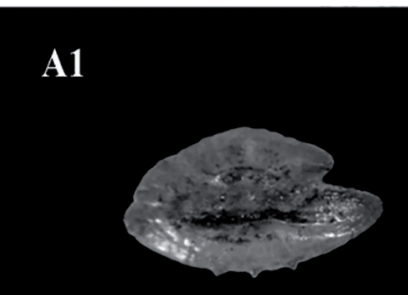

A2

B1

$1 \mathrm{~mm}$

$1 \mathrm{~mm}$

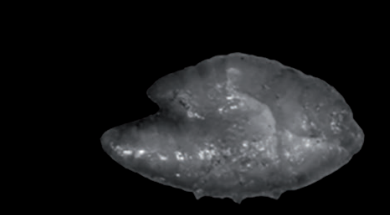

B2

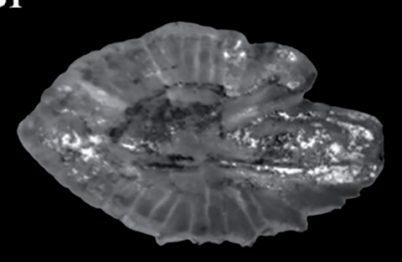

C1

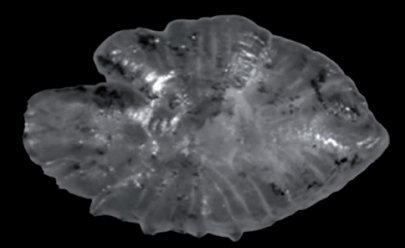

C2
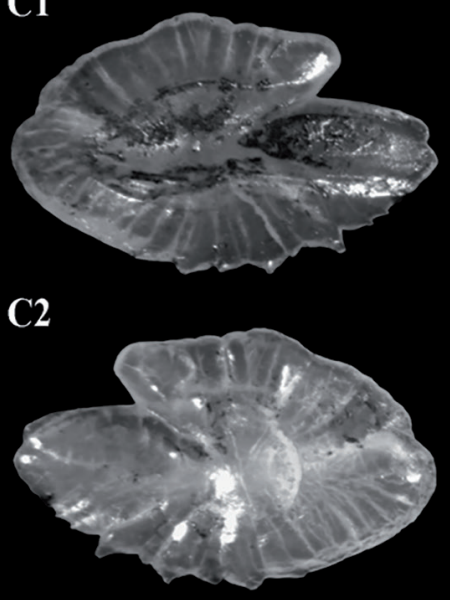

A3

B3

C3
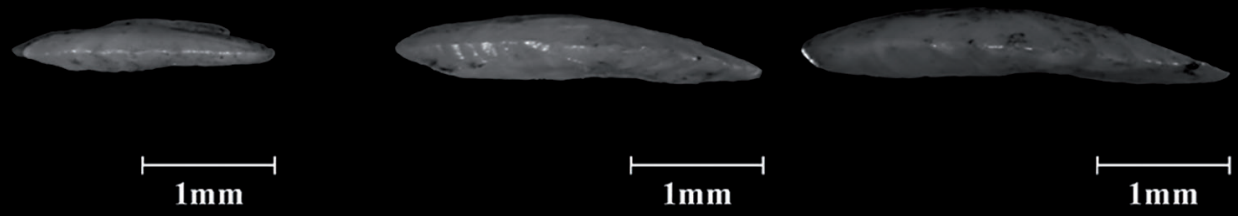

$1 \mathrm{~mm}$

Plate 8. Illustrations (above) and photographs (below) of Anchoviella lepidentostole otoliths from fishes with total lengths: A. 75 $\mathrm{mm}$; B. $102 \mathrm{~mm}$; C. $126 \mathrm{~mm}$. The medial face is shown in A1, B1, C1; the lateral face in A2, B2, C2; the ventral profile in A3, B3, C3 (Illustration: Silvia de Almeida Gonsales; Photos: Alexandre Arackawa). 

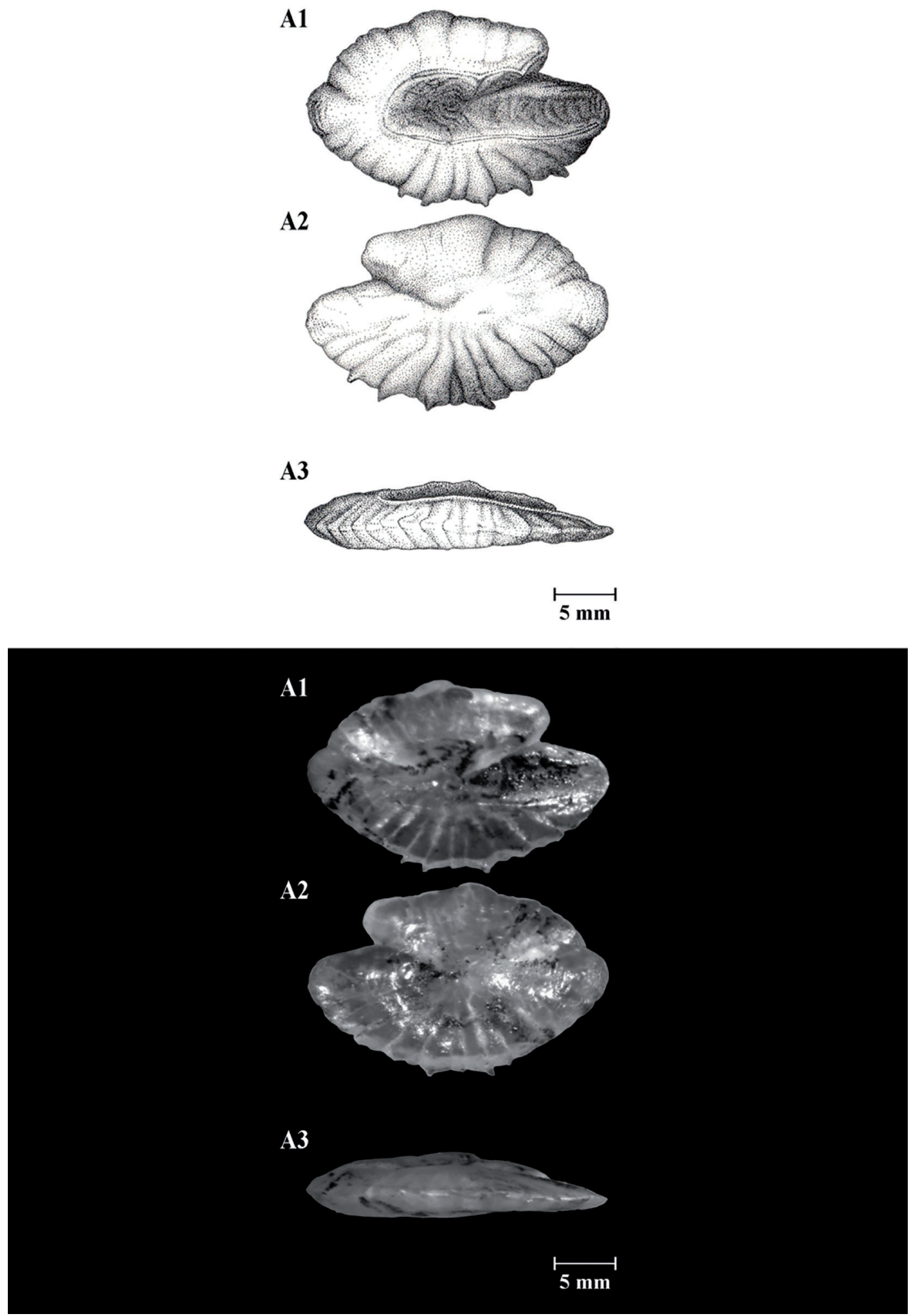

Plate 9. Illustrations (above) and photographs (below) of Cetengraulis edentulus otolith from a fish with total length of $93 \mathrm{~mm}$. The medial face is shown in A1; the lateral face in A2; and the ventral profile in A3 (Illustration: Alexandre Arackawa; Photos: Alexandre Arackawa). 
A1

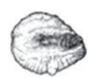

A2

A3<smiles>C1=CCCCC1</smiles>

A1

A2

A3

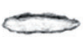

B1

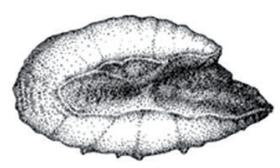

B2

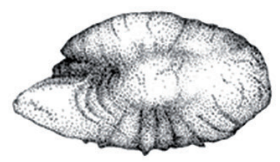

B3

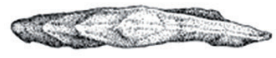

C1

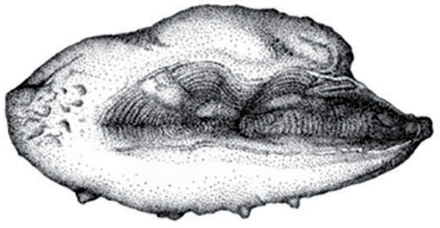

C2

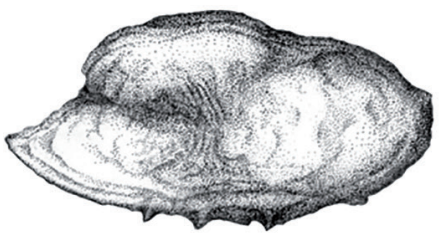

C3

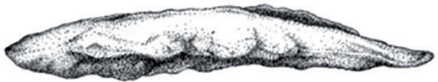

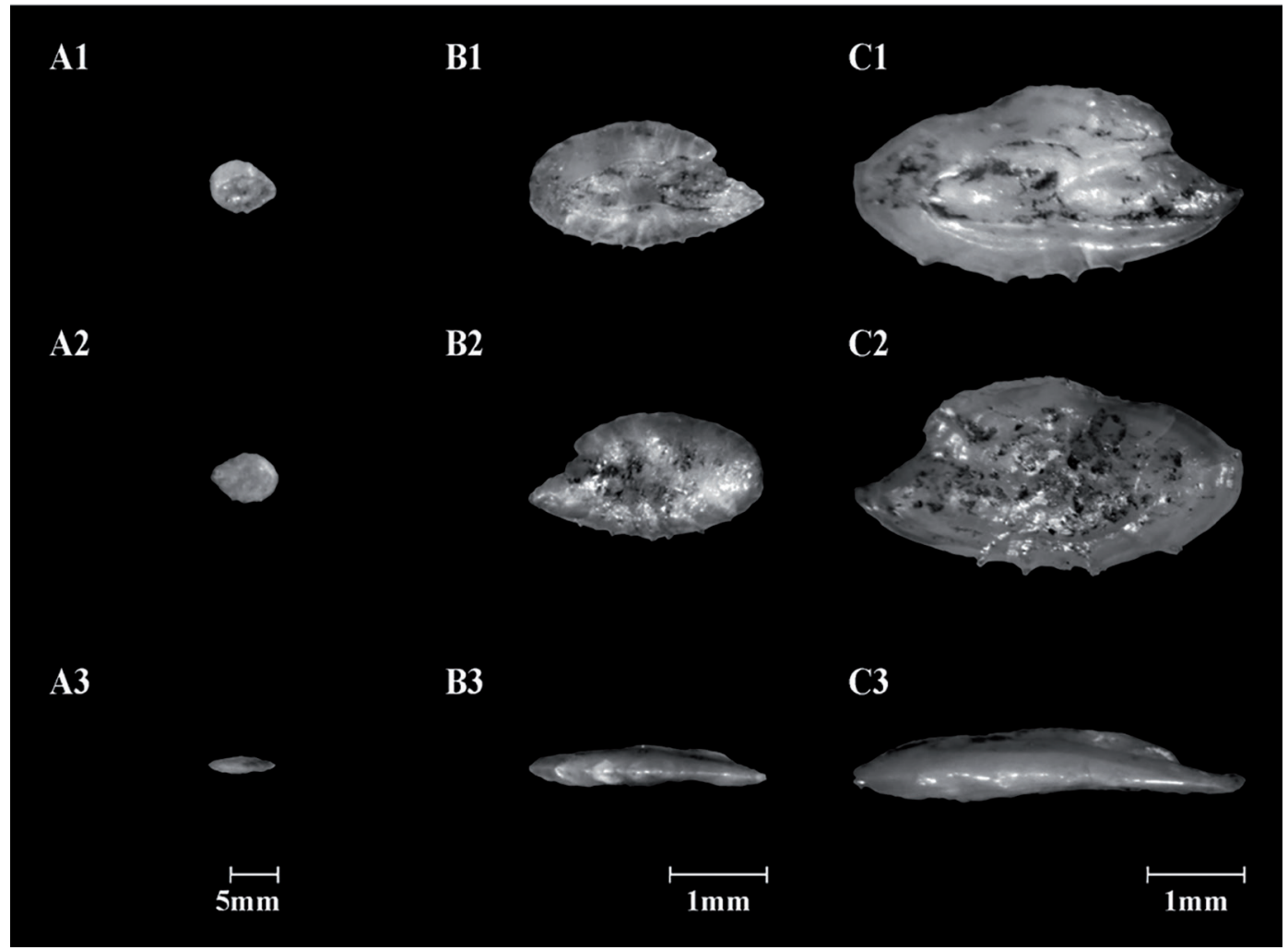

Plate 10. Illustrations (above) and photographs (below) of Engraulis anchoita otoliths from fishes with total lengths: A. $41 \mathrm{~mm}$; B. $102 \mathrm{~mm}$; C. $165 \mathrm{~mm}$. The medial face is shown in A1, B1, C1; the lateral face in A2, B2, C2; the ventral profile in A3, B3, C3 (Illustration: Alexandre Arackawa; Photos: Alexandre Arackawa). 
A1

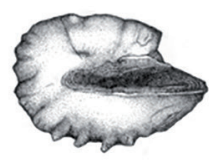

A2

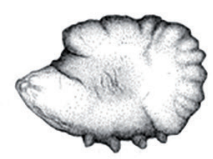

A3

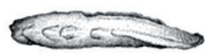

B1

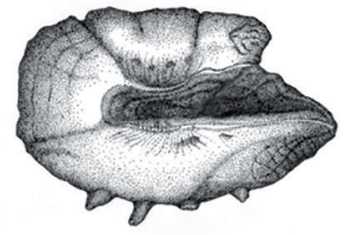

B2

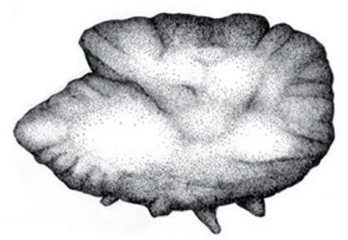

B3

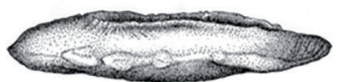

C1

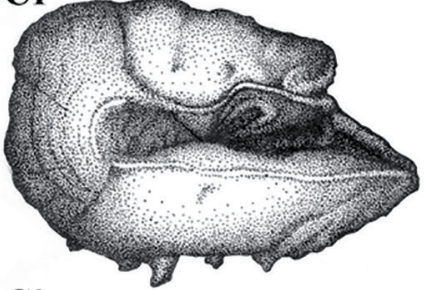

C2

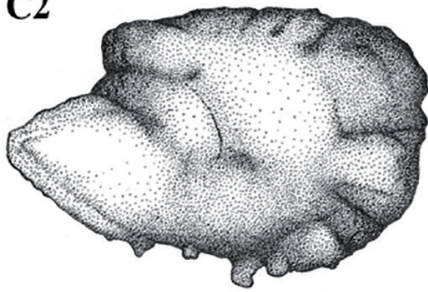

C3

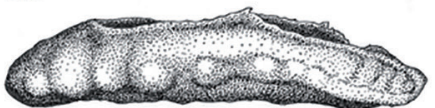

\section{$1 \mathrm{~mm}$}

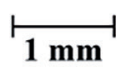

\section{$\vdash \mathbf{m m}$}

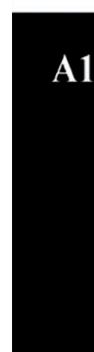

A2

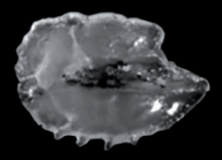

A2

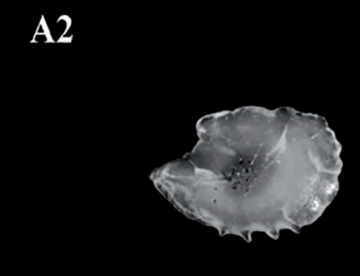

B2

A3

B3
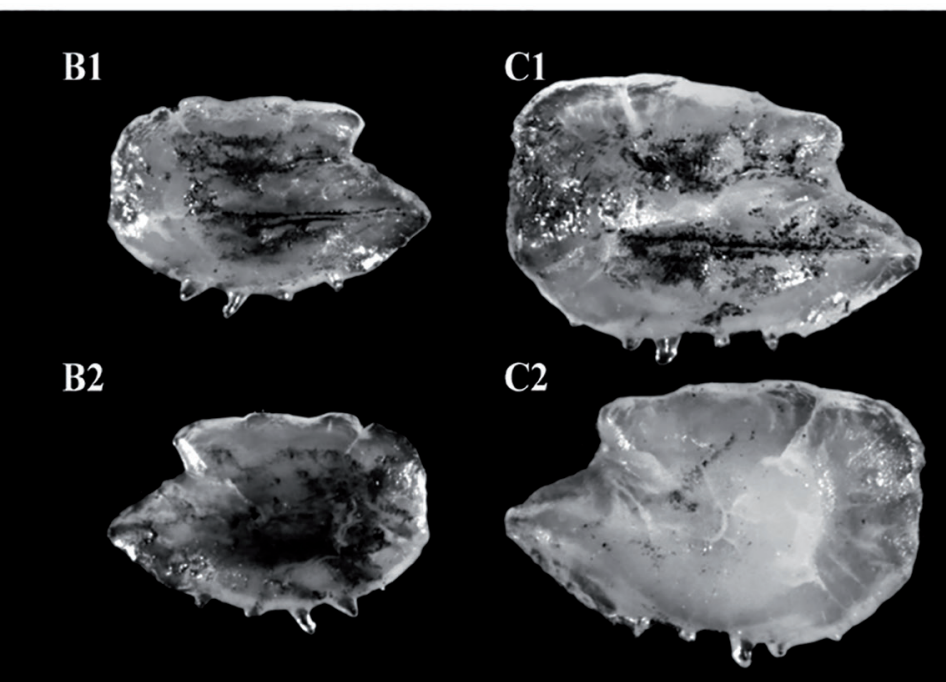

C3

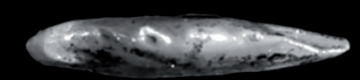

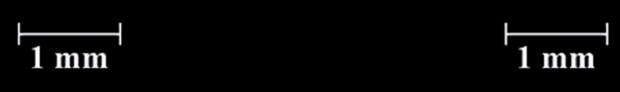

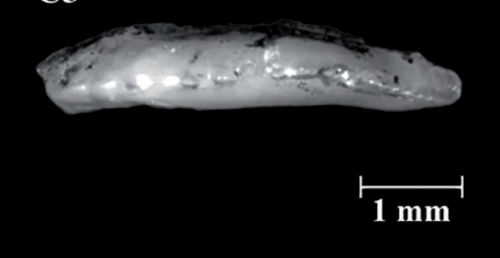

Plate 11. Illustrations (above) and photographs (below) of Chirocentrodon bleekerianus otoliths from fishes with total length: A. $65 \mathrm{~mm}$; B. $92 \mathrm{~mm}$; C. $116 \mathrm{~mm}$. The medial face is shown in A1, B1, C1; the lateral face in A2, B2, C2; the ventral profile in A3, B3, C3 (Illustration: Alexandre Arackawa; Photos: Cesar Santificetur). 
A1

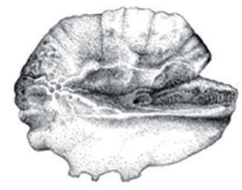

A2

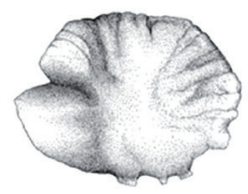

A3
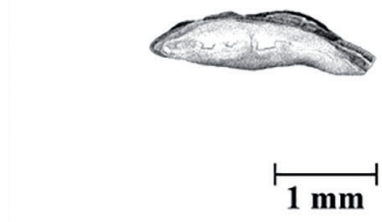

B1

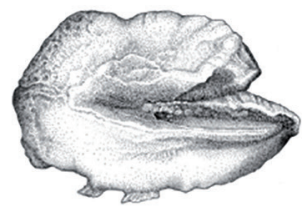

B2

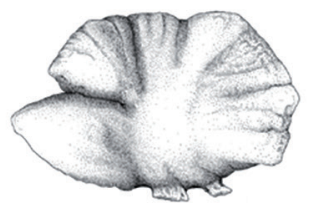

B3

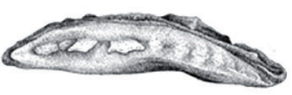

$\longmapsto$

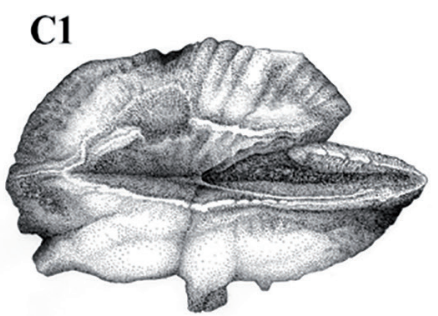

C2

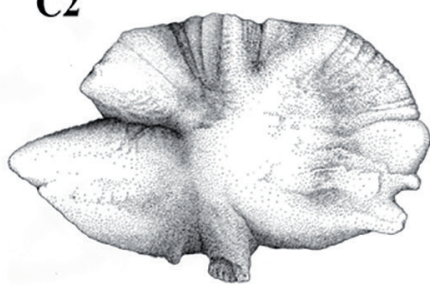

C3

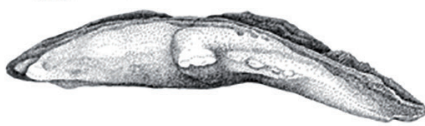

B1
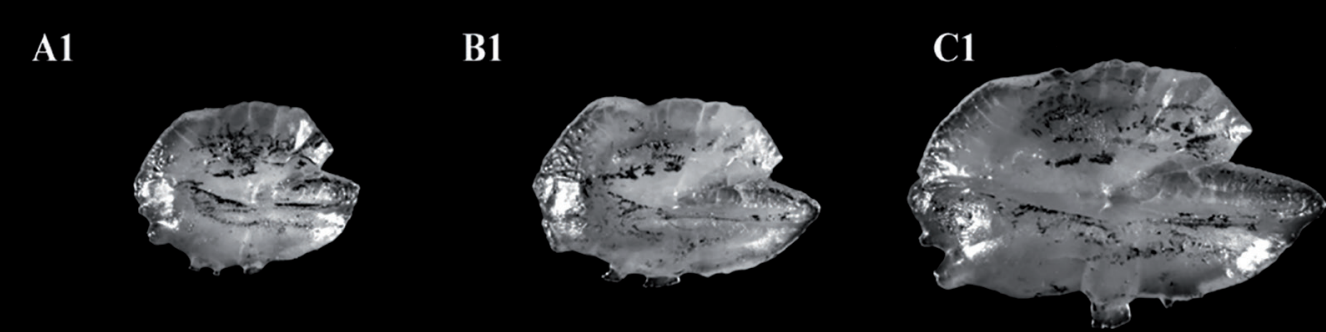

A2

B2
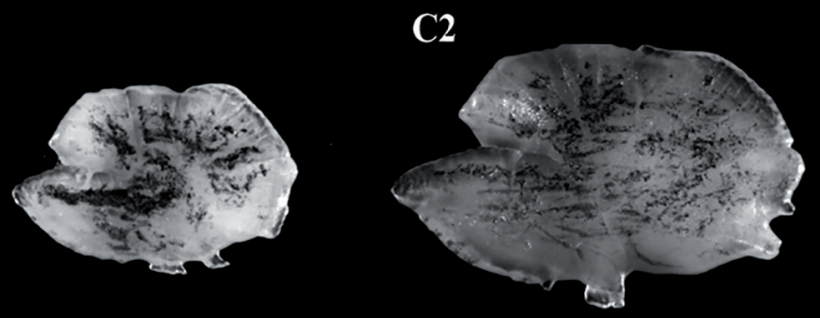

$\longmapsto \mathrm{mm}$

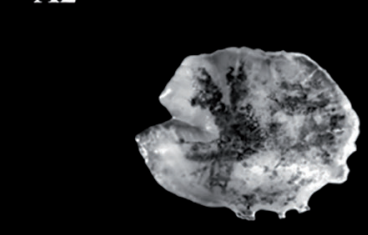

A3

B3

\section{C3}
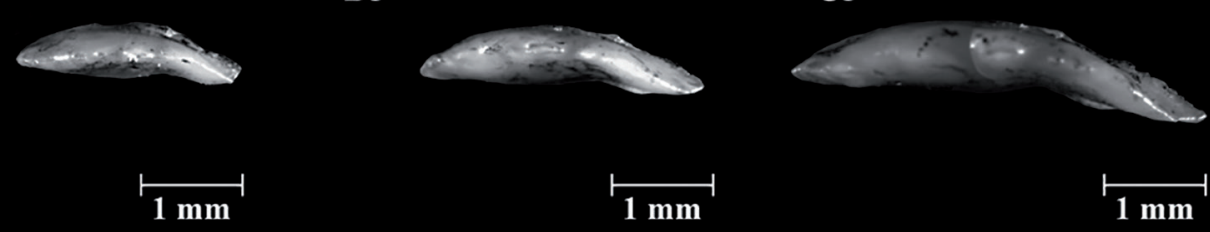

Plate 12. Illustrations (above) and photographs (below) of Pellona harroweri otoliths from fishes with total length: A. 93 mm; B. 123 $\mathrm{mm}$; C. $154 \mathrm{~mm}$. The medial face is shown in A1, B1, C1; the lateral face in A2, B2, C2; the ventral profile in A3, B3, C3 (Illustration: Silvia de Almeida Gonsales; Photos: Cesar Santificetur). 